\title{
IMPROVEMENT OF THE CULTIVATION TECHNOLOGY OF WHITE ANNUAL MELILOT IN THE CONDITIONS OF SOUTHERN STEPPE OF UKRAINE
}

\author{
Vlashchuk A. M.
}

\section{INTRODUCTION}

Today, in Ukraine, the most reliable fixed asset not only for agricultural production, but also for the country's economy is land. Most producers have a standard crop rotation: fallow field - winter wheat - winter rape (sunflower) -sorghum, which lacks the elementary possibility of natural restoration of soils fertility. All these crops require significant doses of nitrogen fertilizers, the prices of which have recently grown too much. Therefore, from the point of basics of soil fertility maintenance, it is necessary to observe the basic laws of agriculture, which foresee a crop rotation with the obligatory cultivation of legumes. At the irrigated lands, it is, first of all, soybean. At the rain-fed lands pea could be used ${ }^{1,2}$.

The cultivation of rare but highly productive legumes, which are multifunctional in use, will increase soil fertility, increase crop production and reduce forage and protein deficiency. Therefore, in Southern Steppe of Ukraine - in the area of risky agriculture, it is advisable to sow the annual white melilot as a drought-tolerant crop. This is especially the case with saline soils. White annual melilot is the crop that can recultivate saline lands - it grows on the grasslands where most plants do not grow. Therewith, this legume is very responsive to irrigation, increasing its productivity by one and a half to two times. This species is one of the best nitrogen fixing green manure crop. Burying melilot plants for green manure, up to $150-200 \mathrm{~kg}$ of nitrogen is added to the soil, which is approximately 50-60 tons of

${ }^{1}$ Рудницький Б. О. Удосконалення елементів технології вирощування бобових трав на корм та насіння. Корми і кормовиробництво. 2003. № 51. С. 43-51.

${ }^{2}$ Коць С. Я. Фізіологічні основи підвищення насіннєвої продуктивності люцерни. Физиология и биохимия культурных растений. 2000. Т. 32, № 3 . C. $163-170$. 
manure per 1 ha. Therefore, this crop, undoubtfully, fits perfectly to modern short-rotation crop rotations of the steppe land ${ }^{3,4}$.

The annual white melilot is positioned as a highly productive forage protein plant. Yield of green mass $-30 \mathrm{t} / \mathrm{ha}$, hay $-4 \mathrm{t} / \mathrm{ha}$, seeds $600-1200 \mathrm{~kg} / \mathrm{ha}$. It has been known for a long time for its high quality as a pharmaceutical raw material for the preparation of various environmentally friendly medicines. It is one of the best honey plants, at long flowering - 45-60 days per one hectare of the crops 350-600 lg of sugar in nectar is secreted. The duration of flowering of the crop during two months promotes the prolongation of feed basis presence for wild leafcutting bees, which allows increasing their number. Leafcutting bees are the main, or only, pollinators of forage legumes melilot, alfalfa, et al. ${ }^{5,6}$.

At present, there is almost no data in scientific literature in regard to the development of cultivation technology for the crop with taking into account changes in the current conditions of global climate warming. Considering the fact that no breeding of new varieties is being carried out at present and there is no seed production of annual white clover, and in connection with the study of agro-technology of the new variety, there is a need for scientific research to improve the technology of seed production of this crop.

Therefore, researches on the optimization of cultivation technology of the crop in arid conditions of Southern Steppe of Ukraine are of current interest.

During 2016-2018, two experiments were carried out: in the first experiment, we studied seed productivity of annual white melilot depending on the sowing time and sowing rates: factor $\mathrm{A}$ - sowing time: the third decade of March, the first decade of April, the second decade of April; factor B - sowing rate: 1.5 million pieces/ha, 2.5 and 3.5 million pieces/ha. The second experiment covered the study of seed

3 Петриченко В. Ф. Наукові основи інтенсифікації польового кормовиробництва в Україні. Вінниця: ФОП Данилюк В.Г., 2008. 246 с.

${ }^{4}$ Шлапунов В. Н. Донник белый - конкурент люцерне и клеверу. Гомель: Белорусское сельское издательство, 2008. 446 с.

${ }^{5}$ Кирпичев И. В., Наумов С. Ю. Однолетний и двулетний донник. Луганск: Укрроспроммаш, 2000. 356 с.

${ }^{6}$ Влащук А. М., Прищепо М. М., Конащук О. П., Колпакова О. С. Буркун білий однорічний - перспективна кормова культура. Агроном. 2015. № 3(49). С. 216-218. 
productivity of the studied crop depending on the application of herbicides and the rate of their application: Factor A - herbicide: control (without herbicides), herbicides Treflan and Pulsar; factor B - application rate: for Treflan preparation $-1.5 \mathrm{~L} / \mathrm{ha}, 2.5 \mathrm{~L} / \mathrm{ha}$, 3.0 L/ha, 4.0 L/ha, for Pulsar preparation - $0.5 \mathrm{~L} / \mathrm{ha}, 0.75 \mathrm{~L} / \mathrm{ha}$, $1.0 \mathrm{~L} / \mathrm{ha}, 1.5 \mathrm{~L} / \mathrm{ha}$.

\section{Seed yield of annual white melilot depending on sowing time and sowing rates in Southern Steppe of Ukraine}

The aim of the study was to determine the yield and sowing qualities of annual white melilot depending on the sowing time and sowing rates in Southern Steppe of Ukraine.

Field double-factored experiment was conducted by the method of split plots according to the common methods of field experiment conduction and methodological recommendations ${ }^{7,8}$ at the research field of the Institute of Irrigated Agriculture of the National Academy of Agrarian Sciences of Ukraine in 2016-2018.

The researches were carried out in four replications, with randomized way of the variants distribution. The area of the sites of the first order $-62 \mathrm{~m}^{2}$, of the second order $-25 \mathrm{~m}^{2}$. The soil of the experimental plot is dark chestnut, medium-loamy, slightly saline, the soil-forming rock of which is loess-like loam.

The analysis of literature sources testifies that the maximum seed productivity of melilot can be obtained only under the conditions of differentiated selection of the plants density, taking into account natural and climatic conditions. Under the correct quantitative distribution of plants on the growing area, which is stipulated by the sowing rate, the phytosanitary condition of the crops, water, air and nutritional regime of the soil improves; favorable conditions are created for the increase of the crop productivity ${ }^{9,10}$.

7 Єщенко В.О., Копитко П.Г., Опришко В.П., Костогриз П.В. Основи наукових досліджень в агрономії: монографія. Київ: Вид. Дія, 2005. С. 288 с.

8 Ушкаренко В.О., Вожегова Р.А., Голобородько С.П., Коковіхін С.В. Методика польового дослід. Херсон: Грінь Д. С., 2014. 286 с.

${ }^{9}$ Наумов С.Ю., Полищук С.П., Шелихов П. В. Местные популяции белого донника и их роль при селекции на продуктивность. Збірник наукових праць Луганського державного аграрного університету. 2001. № 11(23). С. 71-74.

10 Архипенко Ф.М. Кормовиробнитво в умовах зростання посушливості клімату. Вісник аграрної науки. 1994. № 9. С. 36-40. 
Formation of optimal plant density of melilot at different time of sowing per unit of the area is an important agrotechnical technique for the increase in crop yields. Thus, we determined the dependence of seed productivity of melilot in dependence on different sowing times and sowing rates (Table 1.1).

By the results presented in the Table we see that at the time of the sprouting higher plants density was determined in the crops of the second time of sowing and it was $67.8-85.6 \mathrm{pc} . / \mathrm{m}^{2}$, but at the moment of harvesting higher index of plants density of melilot was fixed in the crops of the third time of sowing and it was $57.3-73.9 \mathrm{pc} . / \mathrm{m}^{2}$.

Table 1.1

Influence of sowing time and sowing rate on the plants density of annual white melilot, average for 2016-2018

\begin{tabular}{|c|c|c|c|c|}
\hline \multirow{2}{*}{$\begin{array}{l}\text { Factor A, } \\
\text { time } \\
\text { of sowing }\end{array}$} & \multirow{2}{*}{$\begin{array}{c}\text { Factor } \mathrm{B}, \\
\text { sowing } \\
\text { rate, } \\
\text { million }\end{array}$} & \multicolumn{3}{|c|}{$\begin{array}{l}\text { Time of the determination } \\
\text { of plants density, } \mathrm{pc} . / \mathrm{m}^{2}\end{array}$} \\
\hline & & sprouting & $\begin{array}{l}\text { before } \\
\text { flowering }\end{array}$ & $\begin{array}{c}\text { before } \\
\text { harvesting }\end{array}$ \\
\hline \multirow{3}{*}{$\begin{array}{l}\text { III decade } \\
\text { of March }\end{array}$} & 1.5 & 62.7 & 54.8 & 54.0 \\
\hline & 2.5 & 74.8 & 68.4 & 64.5 \\
\hline & 3.5 & 81.7 & 73.2 & 68.9 \\
\hline \multirow{3}{*}{$\begin{array}{l}\text { I decade } \\
\text { of April }\end{array}$} & 1.5 & 67.8 & 57.9 & 54.2 \\
\hline & 2.5 & 80.6 & 73.8 & 69.9 \\
\hline & 3.5 & 85.6 & 76.0 & 70.7 \\
\hline \multirow{3}{*}{$\begin{array}{l}\text { II decade } \\
\text { of April }\end{array}$} & 1.5 & 65.3 & 59.4 & 57.3 \\
\hline & 2.5 & 78.9 & 71.1 & 69.2 \\
\hline & 3.5 & 83.2 & 78.4 & 73.9 \\
\hline
\end{tabular}

The highest index of the height of melilot plants of $155-160 \mathrm{~cm}$ was determined at sowing the crop in the I decade of April with the rate of 2.5 million pc./ha (Table 1.2). The maximum growth of the plants was observed in the inter-stage period flowering - seeds formation. 
Table 1.2

Dynamics of growth of annual white melilot plants depending on the times of sowing and sowing rates, average for 2016-2018

\begin{tabular}{|c|c|c|c|c|c|c|}
\hline \multirow[b]{2}{*}{$\begin{array}{c}\text { Factor A, } \\
\text { time } \\
\text { of sowing }\end{array}$} & \multirow[b]{2}{*}{$\begin{array}{c}\text { Factor B, } \\
\text { sowing } \\
\text { rate, } \\
\text { million } \\
\text { pc./ha }\end{array}$} & \multicolumn{5}{|c|}{ Phenological stages, $\mathrm{cm}$} \\
\hline & & 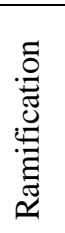 & 告 & 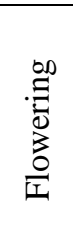 & 䜦 & 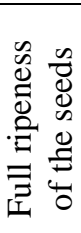 \\
\hline \multirow{3}{*}{$\begin{array}{l}\text { III decade } \\
\text { of March }\end{array}$} & 1.5 & 10 & 140 & 144 & 145 & 143 \\
\hline & 2.5 & 12 & 148 & 151 & 151 & 148 \\
\hline & 3.5 & 11 & 135 & 139 & 138 & 136 \\
\hline \multirow{3}{*}{$\begin{array}{l}\text { I decade } \\
\text { of April }\end{array}$} & 1.5 & 13 & 150 & 150 & 158 & 156 \\
\hline & 2.5 & 15 & 155 & 157 & 160 & 158 \\
\hline & 3.5 & 14 & 146 & 150 & 155 & 153 \\
\hline \multirow{3}{*}{$\begin{array}{l}\text { II decade } \\
\text { of April }\end{array}$} & 1.5 & 11 & 141 & 146 & 150 & 147 \\
\hline & 2.5 & 13 & 149 & 154 & 155 & 153 \\
\hline & 3.5 & 10 & 137 & 140 & 151 & 148 \\
\hline
\end{tabular}

Climate of Southern Steppe of Ukraine is continental, hot, and dry. The annual income of insolation in Kherson region is $115-116 \mathrm{kcal} / \mathrm{cm}^{2}$, among which $94-95 \mathrm{kcal} / \mathrm{cm}^{2}$ are coming during the vegetation period. The income of photosynthetically active radiation (PAR) for the vegetation period is $45-50 \mathrm{kcal} / \mathrm{cm}^{2}$. The annual sum of precipitation fluctuates within $350-470 \mathrm{~mm}$ with the changes by years from $140-160$ to $600-660 \mathrm{~mm}$. Hydrothermal coefficient (HTC) in the region is 0.4-0.5, whereas in the zone of sufficient humidification - 1.0. The major amount of precipitation 
$(50-70 \%)$ is in the warm period of year. Long rain-free periods lasting 50-60 days are typical.

Weather conditions in the years of the trials conduction were typical for Southern Steppe zone of the country. The maximum precipitation amount - $218 \mathrm{~mm}$ was observed in 2016, there were much less precipitation in 2017 and 2018, 172 and $150 \mathrm{~mm}$, respectively. It was defined that the total water consumption of the crop changes in dependence on the time of sowing and sowing rates. The lowest coefficient of water use $-57.3 \mathrm{~m}^{3} / \mathrm{t}$ was determined at sowing in the I decade of April at the rate of 2.5 million pc./ha (Table 1.3).

Table 1.3

Water consumption of annual white melilot depending on the time of sowing and sowing rate, average for 2016-2018

\begin{tabular}{|c|c|c|c|c|c|c|}
\hline 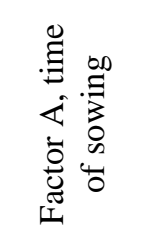 & 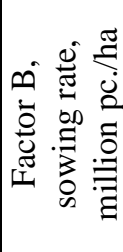 & 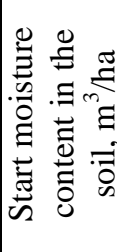 & 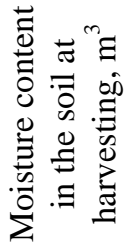 & 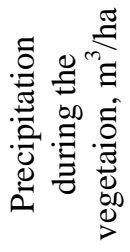 & 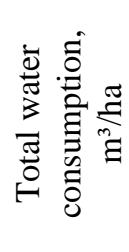 & 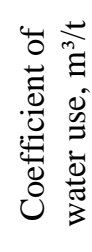 \\
\hline \multirow{3}{*}{$\begin{array}{l}\text { III decade } \\
\text { of March }\end{array}$} & 1.5 & 1174 & 503 & 161.0 & 832 & 105.3 \\
\hline & 2.5 & 1169 & 491 & 161.0 & 839 & 101.1 \\
\hline & 3.5 & 1171 & 484 & 161.0 & 848 & 146.2 \\
\hline \multirow{3}{*}{$\begin{array}{l}\text { I decade } \\
\text { of April }\end{array}$} & 1.5 & 973 & 489 & 151.2 & 635 & 73.8 \\
\hline & 2.5 & 962 & 475 & 151.2 & 638 & 63.2 \\
\hline & 3.5 & 970 & 468 & 151.2 & 653 & 90.7 \\
\hline \multirow{3}{*}{$\begin{array}{l}\text { II decade } \\
\text { of April }\end{array}$} & 1.5 & 1175 & 476 & 152.5 & 852 & 127.2 \\
\hline & 2.5 & 1168 & 464 & 152.5 & 857 & 105.7 \\
\hline & 3.5 & 1172 & 459 & 152.5 & 866 & 151.9 \\
\hline
\end{tabular}

The maximum seed yield of melilot is formed in the conditions of the optimum ratio of all the constituent elements. At the insufficient development of one constituent element yield could be compensated at the expense of other components. As separate components are formed at different stages of organogenesis they require optimal environmental conditions for its successful development. Realization of the laid 
reproductive elements of the melilot plants begins with the start of flowering stage when water consumption of the plants increases. At the favorable environmental conditions flowering stage lasts for 1.5-2 and more months.

The researches conducted in 2016-2018 showed that sowing rate had significant effect on the formation of seed yield of annual white melilot. Depending on the factors of the trial, the plants are falling in different agrometeorological conditions, grow and develop differently, i.e., they form different productivity. Seed yield of melilot at different times of sowing and sowing rates varied from $0.57 \mathrm{t} / \mathrm{ha}$ to $1.01 \mathrm{t} / \mathrm{ha}$ (Table 1.4).

Table 1.4

Seed yield of annual white melilot depending on times of sowing and sowing rates, average for 2016-2018

\begin{tabular}{|c|c|c|c|c|}
\hline \multirow{2}{*}{$\begin{array}{l}\text { Factor A, } \\
\text { time of } \\
\text { sowing }\end{array}$} & \multirow{2}{*}{$\begin{array}{c}\text { Factor } \mathrm{B}, \\
\text { sowing rate, } \\
\text { million pc./ha }\end{array}$} & \multicolumn{3}{|c|}{ Yield, t/ha } \\
\hline & & $\begin{array}{l}\text { Average for } \\
\text { three years }\end{array}$ & $\begin{array}{c}\text { By } \\
\text { factor A }\end{array}$ & $\begin{array}{c}\mathrm{Be} \\
\text { factor B }\end{array}$ \\
\hline \multirow{3}{*}{$\begin{array}{l}\text { III decade } \\
\text { of March }\end{array}$} & 1.5 & 0.79 & \multirow{3}{*}{0.73} & 0.77 \\
\hline & 2.5 & 0.83 & & 0.88 \\
\hline & 3.5 & 0.58 & & 0.62 \\
\hline \multirow{3}{*}{$\begin{array}{l}\text { I decade } \\
\text { of April }\end{array}$} & 1.5 & 0.86 & \multirow{3}{*}{0.86} & \\
\hline & 2.5 & 1.01 & & \\
\hline & 3.5 & 0.72 & & \\
\hline \multirow{3}{*}{$\begin{array}{l}\text { II decade } \\
\text { of April }\end{array}$} & 1.5 & 0.67 & \multirow{3}{*}{0.68} & \\
\hline & 2.5 & 0.81 & & \\
\hline & 3.5 & 0.57 & & \\
\hline \multicolumn{5}{|c|}{ Evaluation of significance of partial differences } \\
\hline \multirow{2}{*}{$\mathrm{LSD}_{05}$} & $\mathrm{~A}$ & 0.043 & & \\
\hline & $\mathrm{B}$ & 0.035 & & \\
\hline \multicolumn{5}{|c|}{ Evaluation of significance of main effects } \\
\hline \multirow{2}{*}{$\mathrm{LSD}_{05}$} & $\mathrm{~A}$ & 0.025 & & \\
\hline & $\mathrm{B}$ & 0.020 & & \\
\hline
\end{tabular}

It is evident from the Table that all the studied factors affected the formation of seed productivity of annual white melilot. The maximum average yield for 2016-2018 - 1.01 t/ha the crop formed at sowing in 
the I decade of April under the rate of 2.5 million pc./ha $\left(\mathrm{LSD}_{05} \mathrm{~A}-\right.$ $0.025 \mathrm{t} / \mathrm{ha}, \mathrm{B}-0.020 \mathrm{t} / \mathrm{ha}$ ).

The maximum yield by the factor A (sowing time) $-0.86 \mathrm{t} / \mathrm{ha}-$ the plants of annual white melilot formed at sowing in the I decade of April ( $\mathrm{LSD}_{05} \mathrm{~A}-0.43 \mathrm{t} / \mathrm{ha}$ ). By the factor $\mathrm{B}$ (sowing rate) this index reached the maximum at the use of sowing rate 2.5 million $\mathrm{pc}$./ha $0.88 \mathrm{t} / \mathrm{ha}\left(\mathrm{LSD}_{05} \mathrm{~B}-0.35 \mathrm{t} / \mathrm{ha}\right)$.

The results of the study determined that the yield was affected by all the studied factors. But the strongest effect on the seed yield was caused by the time of sowing. On average for 2016-2018, its share was $63.4 \%$, the share of the factor B $-43.8 \%$ (Fig. 1.1).

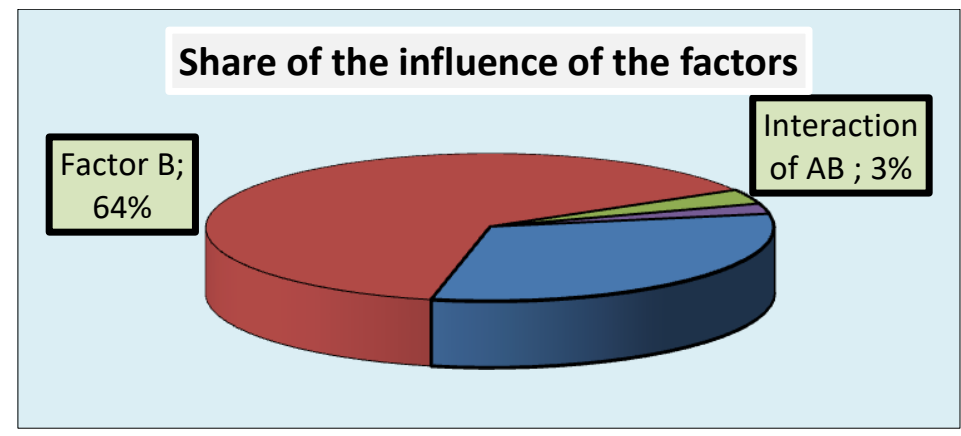

\section{Fig. 1.1. The share of the effect of the studied factors on the seed yield of annual white melilot, average for 2016-2018}

Economic efficiency of new variety of annual white melilot depends mainly on the seed yield, its quality and price, and also on the money saving for the cultivation. The results of economic analysis for the years of the study testify that all the studied factors affect the economic efficiency indexes of the crop cultivation.

The prices for the seeds of white melilot were used in accordance with the data of the Institute of Irrigated Agriculture of NAAS and were $100 \mathrm{UAH} / \mathrm{kg}(100,000 \mathrm{UAH} / \mathrm{t}$ of the seeds $)$ of elite seed material. These data were used in the calculations of the main indexes of economic efficiency.

It was determined that among the studied times of sowing the maximum profitability of $355 \%$ was achieved at sowing in the I decade of April, the minimum index of $256 \%$ was defined at sowing in the 
II decade of April. Among the studied sowing rates the maximum profitability of $342 \%$ was obtained at 2.5 million pc.ha, the minimum $238 \%$ at sowing rate of 3.5 million pc.ha (Fig. 1.2, 1.3).

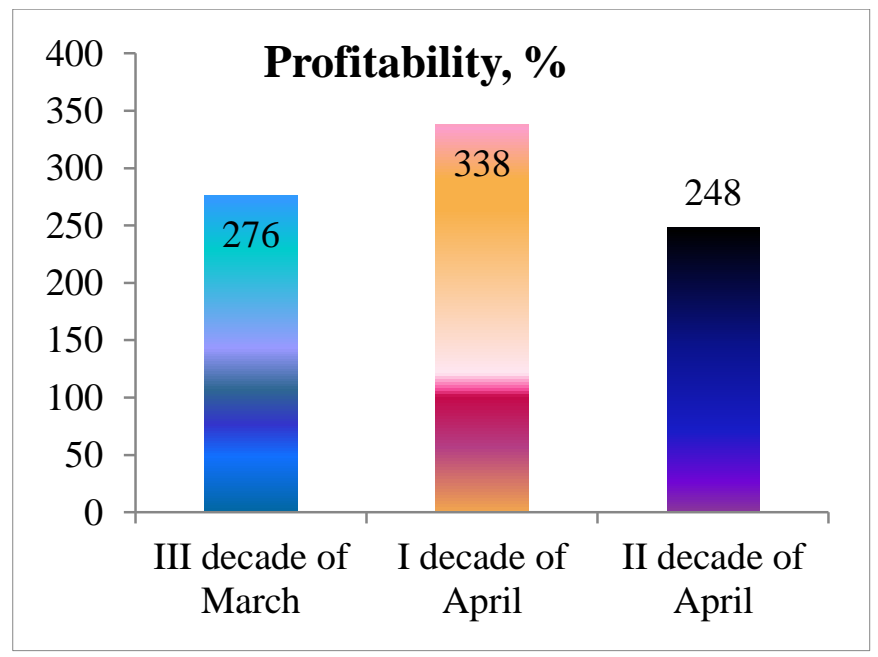

Fig. 1.2. Profitability of annual white melilot variety Pivdennyi depending on time of sowing, average for 2016-2018

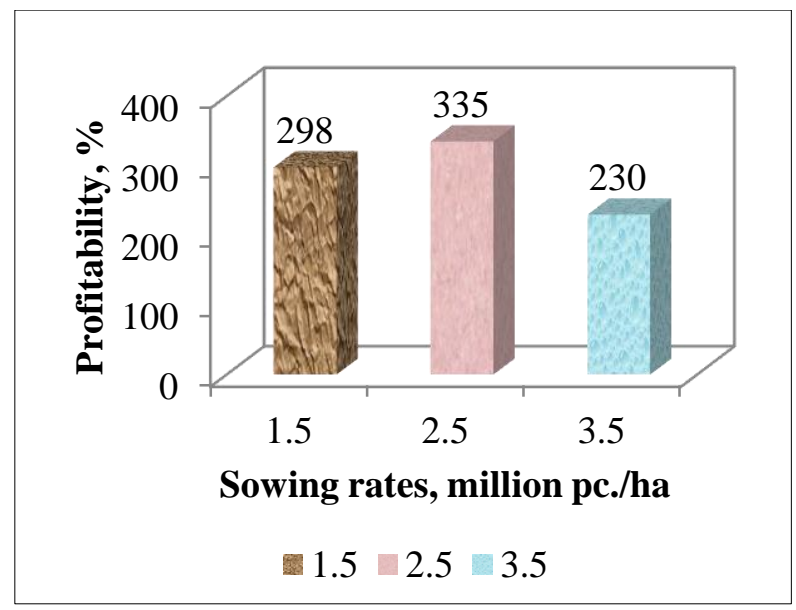

Fig. 1.3. Profitability of annual white melilot variety Pivdennyi depending on sowing rate, average for 2016-2018 
This is explained by the fact that seed productivity of annual white melilot is in direct dependence on soil and climatic conditions of the zone of cultivation. Therefore, to obtain the maximum seed yield of annual white melilot in Southern Steppe of Ukraine it is recommended to sow the crop in the I decade of April with the rate of 2.5 million pc./ha.

\section{Seed yield of annual white melilot depending on the application of herbicides in the conditions of Southern Steppe of Ukraine}

The aim of the study was to determine the yield and sowing qualities of annual white melilot depending on the application of herbicides and their application rates in the conditions of Southern Steppe of Ukraine.

The tasks of the study include:

- the determination of weed species and the level of weed contamination of the crop;

- the determination of technical efficiency of different herbicides application rates against weeds in the melilot crop;

- the determination of seed productivity of annual white melilot depending on the application of different rates of herbicides;

- the determination of the optimal application rate for the most efficient herbicide against weeds in the crop of annual white melilot in the conditions of theSouth of Ukraine at different application rates;

- the determination of economic and energy efficiency of annual white melilot cultivation depending on the application of different rates of herbicides in Southern Steppe of Ukraine.

The experiment is double-factored, in four replications, the variants are placed by using the randomized split plots with accordance to generally accepted methods of field trials conduction at the experimental field of the Institute of Irrigated Agriculture of NAAS in 2016-2018 ${ }^{11}$. The experimental area was $900 \mathrm{~m}^{2}$, the area of a single plot $-24 \mathrm{~m}^{2}$. The soil of the experimental field was dark-shestnut, middle-loamy, slightly saline, with the loess-like loam soil-forming rock material.

11 Бабич А.О. Методика проведення дослідів по кормовиробництву. Вінниця: Іскра, 1994. 87 с. 
Quantitative and balance registration of weeds was performed on five areas, each of which was $0.5 \mathrm{~m}^{2}$. At the first registration -10 days after the application of herbicides - quantitative registration, before harvesting - quantitative and balance one. Annual white melilot variety Pivdennyi was sown in the experiment.

To obtain planned and qualitative yield of the crop it is obligatory to conduct recommended and various measures for control of quantity and development of weeds. Among the recommended and such that provide reliable protection of crop sprouts there is a measure of weed control through the application of soil herbicides. One of the valuable advantages of soil herbicides is the possibility of their use through the soil spraying before sowing, a the moment of sowing and even after sowing before the sprouts appear ${ }^{12}$.

With the aim of provision of planned and qualitative yield of crops and efficient weed control it is necessary to take into account such an index as their selectivity. Selective herbicides are divided into soil and post-sprouting. Soil (basic) herbicides are mostly used before sprouts of crops appear. Their features include the formation of protective shield and oppression of weeds germination. Therefore, soil herbicides are applied mainly for the limitation of annual weeds. The advantage of soil herbicides is a possibility to control several waves of germinating weeds that provides powerful start for crop sprouts. Technical efficiency of soil herbicides depends on moisture and quality of soil tillage ${ }^{13}$.

The main advantage of these herbicides is the duration of protective activity, which is often spread for the whole vegetation period. Their advantages also include the fact that their toxic activity almost is not dependent on weather conditions. In contrary, precipitation only amplify the effect of the preparations through more equal distribution in soil; the influence of wind is manifested less because big-drip sprinkling through the sprayers with big outlets, which are not clogged with side dashes, are used. To the advantages of

12 Макрушин М.М. Насіннєзнавство польових культур. Київ: Урожай, 1994. $208 \mathrm{c}$.

13 Голобородько С.П., Снеговой В.С., Сахно Г.В. Люцерна. Херсон: Айлант, 2007. 328 с. 
soil preparations should be attributed the possibility of their application with other agricultural operations, e.g., sowing, cultivation, dragging, etc. The disadvantage of this kind of herbicides is, in particular cases, dependence of their efficiency from soil moisture. As a rule, technical efficiency of soil preparations, which are located in dry soil layer, is low ${ }^{14,15}$.

In this connection, we tested in our trials herbicides that have different mechanisms of activity. Soil herbicide Treflan 480 . Peculiarities of the application: to achieve the best efficiency of the preparation it should be incorporated into the soil at the depth of 6$8 \mathrm{~cm}$ as soon as possible (during 4 hours after the application). The optimal temperature of environment for the application of the preparation is $+5{ }^{\circ} \mathrm{C}$ to $+25^{\circ} \mathrm{C}$. If the herbicide is used with accordance to the recommendations, there are no limitations in the crop rotation. System herbicide Pulsar 40, which is absorbed both by herbage and root system of weeds. Peculiarities of the application: the crops could be treated with the herbicide Pulsar 40 just once a season; it mustn't be used in the mixtures with anticereal herbicides; after the herbicide was used it is not allowed to apply the preparations belonging to the groups of sulfonylurea and imidazolinones; the herbicide Pulsar 40 mustn't be applied in windy (wind speed $>5 \mathrm{~m} / \mathrm{sec}$ ) to avoid its unequal distribution and drift on the neighboring fields; the application of the preparations with the active substance from the group of imidazolinones is allowed just once a three years on the same field; it requires equal distribution through the whole area (overlapping of a syringe passes should be minimum); do not allow drift of the active fluid on the neighboring fields; requires qualitative pre-sowing soil tillage (clods not more than $2 \mathrm{~cm}$ ).

The results of the influence of the preparations are presented in the Table 2.1 .

14 Іващенко О.О. Бур'яни в агрофітоценозах: монографія. Київ: Світ, 2002. $236 \mathrm{c}$.

${ }^{15}$ Швартау В.В. Гербіциди. Київ: Логос, 2009., Т. 2. 1046 с. 
Table 2.1

\section{Influence of the applied herbicides on weed contamination of annual white melilot crop, average for 2016-2018}

\begin{tabular}{|c|c|c|c|c|c|c|c|}
\hline \multirow[b]{2}{*}{ 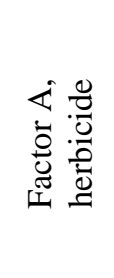 } & \multirow{2}{*}{ 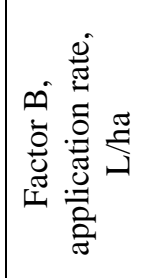 } & \multicolumn{3}{|c|}{$\begin{array}{c}\text { After the application of } \\
\text { herbicide }\end{array}$} & \multicolumn{3}{|c|}{ Before the crop harvesting } \\
\hline & & 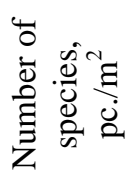 & 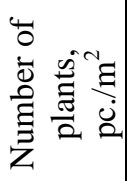 & 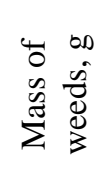 & 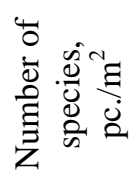 & 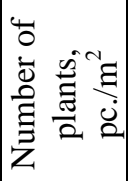 & 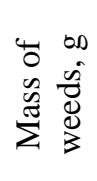 \\
\hline \multirow{5}{*}{$\begin{array}{c}\text { Treflan } \\
480\end{array}$} & Control 1 & 4 & 17 & 206.2 & 5 & 92 & 930.1 \\
\hline & 1.5 & 3 & 12 & 193.3 & 3 & 33 & 598.4 \\
\hline & 2.5 & 3 & 10 & 171.4 & 4 & 20 & 285.5 \\
\hline & 3.0 & 2 & 7 & 151.2 & 4 & 10 & 164.9 \\
\hline & 4.0 & 1 & 6 & 141.8 & 3 & 9 & 138.6 \\
\hline \multirow{5}{*}{$\begin{array}{l}\text { Pulsar } \\
40\end{array}$} & Control 2 & 4 & 16 & 193.7 & 5 & 90 & 908.9 \\
\hline & 0.5 & 4 & 5 & 164.4 & 5 & 11 & 141.7 \\
\hline & 0.75 & 2 & 5 & 154.7 & 4 & 7 & 138.9 \\
\hline & 1.0 & 2 & 3 & 143.6 & 3 & 6 & 127.6 \\
\hline & 1.25 & 1 & 3 & 105.9 & 2 & 4 & 105.1 \\
\hline
\end{tabular}

The main point of the herbicides action is that they oppress the processes of photosynthesis, respiration, nutrients uptake that causes the disturbance of free amino acids synthesis. In connection with this it should be remembered that such actions are possible in the direction of the crop (annual white melilot) in favorable environmental conditions. The degree of the herbicides effect on the crop depends on the application rate and type of herbicide, and on the environmental conditions. The results of such an influence told upon the plants of melilot by the time of the period of full sprouts. So, plant density of the plants of melilot at the treatment with the preparation Treflan 480 was within 53.9-77.2 pc. $/ \mathrm{m}^{2}$, at the application of the herbicide Pulsar $40-$ $80.8-81.9 \mathrm{pc} . / \mathrm{m}^{2}$, that points out on more oppression of the crop at the 
application of Treflan 480, and plant density decreased on the background of higher application rate of the preparation (Table 2.2).

Yield of crops mostly depends on climatic conditions and structural indexes, where perennial and annual herbs as fore-crops in the crop rotation acquire special value. Owing to their strong root system that percolates deep in the soil, the plant of white melilot feels less negative effect of atmospheric drought and lack of moisture in the upper layer of the soil ${ }^{16}$.

Table 2.2

\section{Influence of the application of the herbicides on the plant density of annual white melilot, average for 2016-2018}

\begin{tabular}{|c|c|c|c|c|}
\hline \multirow[b]{2}{*}{$\begin{array}{l}\text { Factor A, } \\
\text { herbicide }\end{array}$} & \multirow{2}{*}{$\begin{array}{l}\text { Factor B, } \\
\text { application } \\
\text { rate, L/ha }\end{array}$} & \multicolumn{3}{|c|}{ Plants density, $\mathrm{pc} . / \mathrm{m}^{2}$} \\
\hline & & $\begin{array}{l}\text { At the } \\
\text { time of } \\
\text { sprouts }\end{array}$ & $\begin{array}{c}\text { Before } \\
\text { flowering }\end{array}$ & $\begin{array}{c}\text { Before } \\
\text { harvesting }\end{array}$ \\
\hline \multirow{5}{*}{$\begin{array}{c}\text { Treflan } \\
480\end{array}$} & Control 1 & 79.9 & 62.4 & 61.1 \\
\hline & 1.5 & 77.2 & 60.2 & 59.7 \\
\hline & 2.5 & 75.1 & 64.4 & 63.1 \\
\hline & 3.0 & 64.5 & 60.8 & 60.0 \\
\hline & 4.0 & 53.9 & 50.1 & 48.5 \\
\hline \multirow{5}{*}{ Pulsar 40} & Control 2 & 79.7 & 61.6 & 60.2 \\
\hline & 0.5 & 81.1 & 63.9 & 63.1 \\
\hline & 0.75 & 80.8 & 66.1 & 65.6 \\
\hline & 1.0 & 81.9 & 68.9 & 68.0 \\
\hline & 1.25 & 81.6 & 65.5 & 64.6 \\
\hline
\end{tabular}

The yield component of annual white melilot are plants density per the unit of area, total number of branches and bunches per plant, average number of seeds per bunch, 1000 seeds weight. At the optimal ratio of these indexes the maximum seed yield is formed, but at the insufficient development of one or more components the yield could be compensated at the expense of other constituents. Separate components are formed at different stages of ontogenesis, therefore they require different agrotechnological conditions for their successful development.

16 Мордерер Є.Ю., Мережинський Ю.Г. Гербіциди. Механізм дії та практика застосування. Київ: Логос, 2009, Т. 1. 380 с. 
High correlation between the seed yield and the number of branches per plant, the number of bunches per plant, the number of seeds per bunch, 1000 seeds weight was determined. The connection between these indexes allowed creation of correlation polynomial models of the dependence of seed yield and different structural indexes (Fig. 2.1, 2.2, 2.3. 2.4).

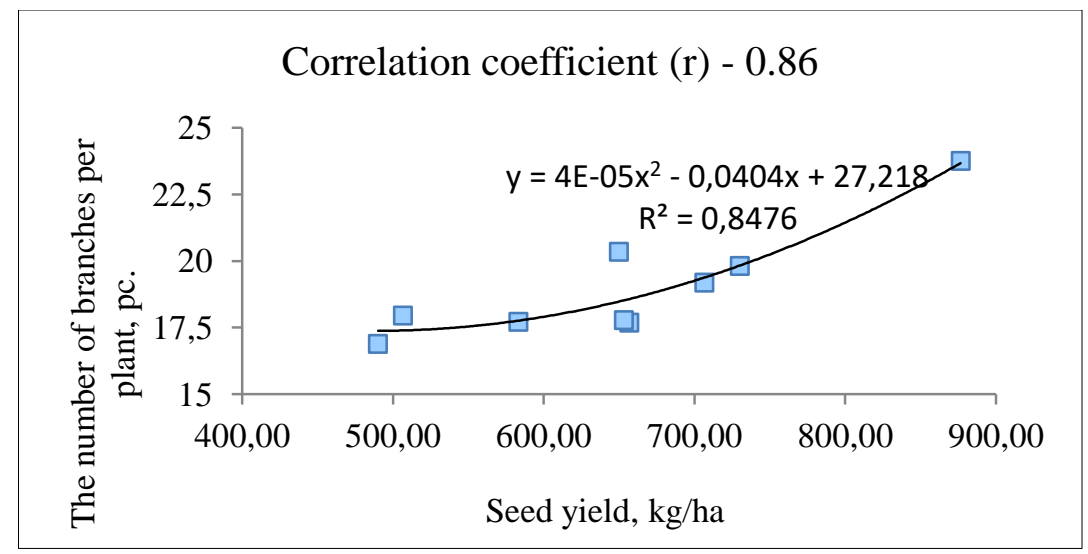

Fig. 2.1. Correlation (r) between the number of branches per plant of white melilot and seed yield (average for 2016-2018)

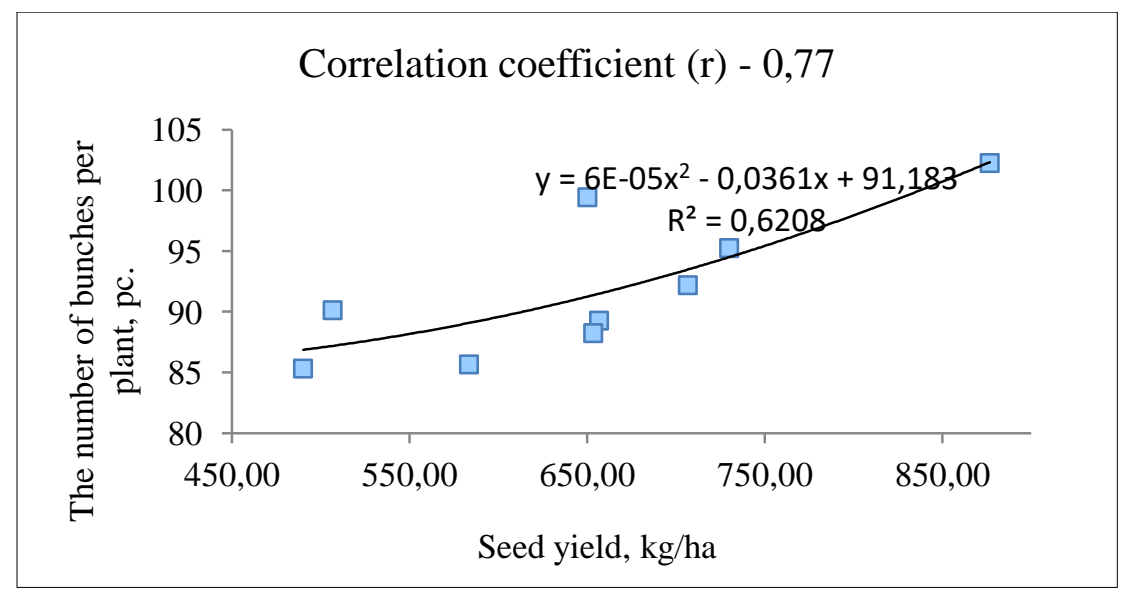

Fig. 2.2. Correlation ( $r$ ) between the number of bunches per plant of white melilot and seed yield (average for 2016-2018) 
This correlation model allowed determination of close connection between the seed yield of white melilot variety Pivdennyi and the number of bunches per plant - the correlation coefficient is 0.77 .

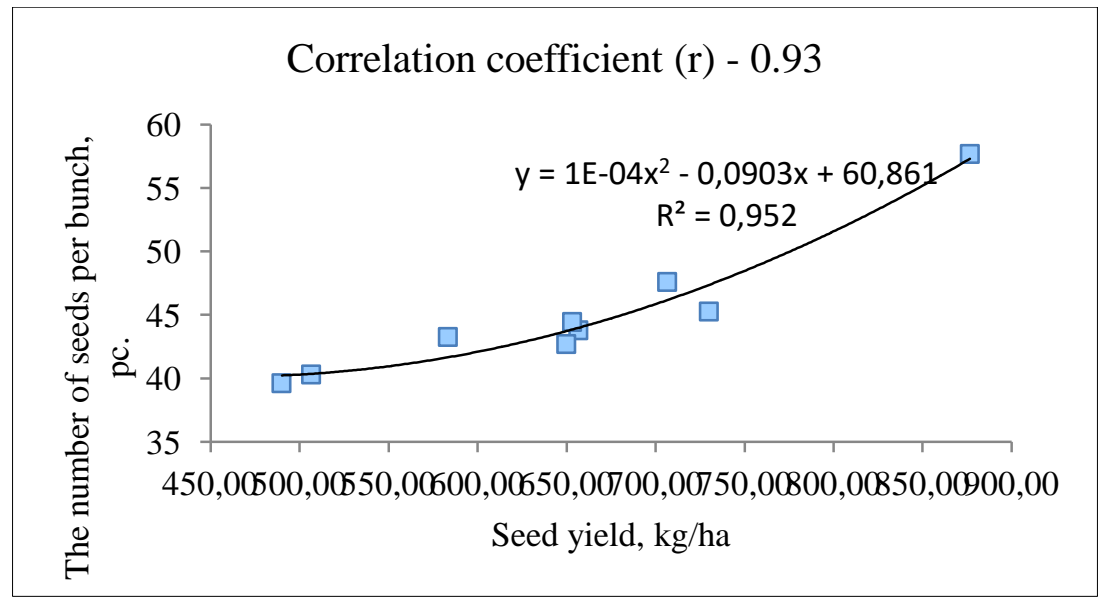

Fig. 2.3. Correlation (r) between the number of seeds per bunch and the seed yield of white melilot (average for 2016-2018)

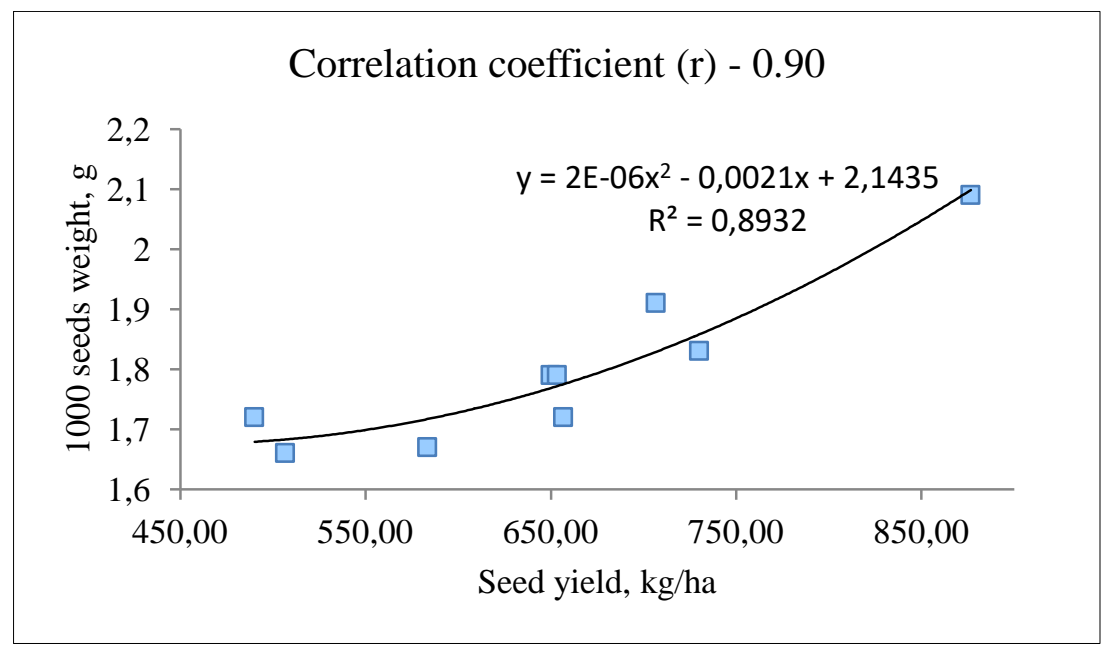

Fig. 2.4. Correlation (r) between 1000 seeds weight and the seed yield of white melilot (average for 2016-2018) 
The modeled indexes prove that the determined number of branches per plant of white melilot differed at different times of sowing and sowing rates. The conducted study showed that at the application of the herbicides with different rates they have significant effect on the development of plants, seed yield formation of annual white melilot. Depending on the factors of the experiment, the plants are coming into different agrometeorological conditions, grow and develop differently, form different yield. The seed yield of annual white melilot at the herbicides application with different rates varied within $0.72 \mathrm{t} /$ ha to $0.92 \mathrm{t} /$ ha (Table 2.3 ).

Table 2.3

The yield of annual white melilot in dependence on the herbicides application, average for 2016-2018

\begin{tabular}{|c|c|c|c|c|c|}
\hline \multirow{2}{*}{$\begin{array}{l}\text { Factor A, } \\
\text { herbicide }\end{array}$} & \multirow{2}{*}{$\begin{array}{c}\text { Factor B, } \\
\text { application rate, } \\
\text { L/ha }\end{array}$} & \multicolumn{2}{|r|}{ Yield } & \multicolumn{2}{|c|}{ By factor } \\
\hline & & $\mathrm{t} / \mathrm{ha}$ & $\begin{array}{c}\text { Additional yield } \\
\mathrm{t} / \mathrm{ha}\end{array}$ & A & B \\
\hline \multirow{5}{*}{ Treflan 480} & Control 1 & 0.58 & - & \multirow{5}{*}{0.77} & 0.59 \\
\hline & 1.5 & 0.74 & 0.16 & & 0.76 \\
\hline & 2.5 & 0.78 & 0.20 & & 0.82 \\
\hline & 3.0 & 0.82 & 0.24 & & 0.87 \\
\hline & 4.0 & 0.72 & 0.14 & & 0.80 \\
\hline \multirow{5}{*}{ Pulsar 40} & Control 2 & 0.60 & - & \multirow{5}{*}{0.86} & \\
\hline & 0.5 & 0.78 & 0.20 & & \\
\hline & 0.75 & 0.86 & 0.28 & & \\
\hline & 1.0 & 0.92 & 0.34 & & \\
\hline & 1.25 & 0.89 & 0.31 & & \\
\hline \multicolumn{6}{|c|}{ Evaluation of significance of partial differences } \\
\hline \multirow{2}{*}{$\mathrm{LSD}_{05}$} & $\mathrm{~A}$ & 0.042 & & & \\
\hline & $\mathrm{B}$ & 0.034 & & & \\
\hline \multicolumn{6}{|c|}{ Evaluation of significance of main effects } \\
\hline \multirow{2}{*}{$\mathrm{LSD}_{05}$} & $\mathrm{~A}$ & 0.017 & & & \\
\hline & $\mathrm{B}$ & 0.024 & & & \\
\hline
\end{tabular}

It is evident from the Table that all the studied factors affected the seed productivity of annual white melilot. The maximum average yield for 2016-2018 - 0.92 t/ha plants of the crop formed at the application of herbicide Pulsar 40 in the rate of $1.0 \mathrm{~L} / \mathrm{ha}\left(\mathrm{LSD}_{05} \mathrm{~A}-0.042 \mathrm{t} / \mathrm{ha}\right.$, $\mathrm{B}-0.034 \mathrm{t} / \mathrm{ha})$. 
The maximum average yield by the factor A (herbicide) $0.86 \mathrm{t} / \mathrm{ha}$, the plants of annual melilot formed at the application of the preparation Pulsar $40\left(\mathrm{LSD}_{05} \mathrm{~A}-0.24 \mathrm{t} / \mathrm{ha}\right)$. By the factor $\mathrm{B}$ (application rate), the maximum index was at the third variant $0.87 \mathrm{t} / \mathrm{ha}\left(\mathrm{LSD}_{05} \mathrm{~B}-0.20 \mathrm{t} / \mathrm{ha}\right)$. On the control plots the yield was lower because of considerable quantity of weeds.

The results of ANOVA determined that the strongest effect on the seed productivity formation of the crop was caused by the factor A (application of a herbicide). In 2016-2018, its share of influence was $43.8 \%$, the share of influence of factor B $-35.8 \%$ (Fig. 2.5).

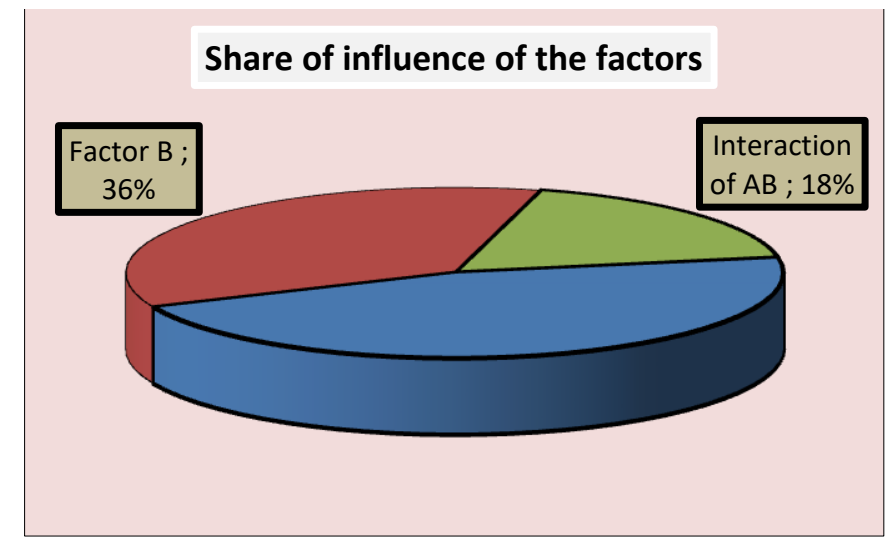

\section{Fig. 2.5. Share of influence of the studied factors on the seed yield of annual white melilot, average for 2016-2018}

Taking in consideration significant fluctuation of seed productivity of annual white melilot variety Pivdennyi, and the indexes of production expenditures, seed production cost and obtained pure profit, the profitability was determined in percents (Fig. 2.6, 2.7). Having conducted the analysis of economic efficiency of the application of preparations Treflan 480 and Pulsar 40 at different application rates we determined that the highest production profitability of $374 \%$ was obtained at the application of Treflan 480 with the rate of $3.0 \mathrm{~L} / \mathrm{ha}$, and Pulsar 40 with the rate of $1.0 \mathrm{~L} /$ ha when profitability reached $415 \%$. The lowest index of profitability was determined on the control plots without chemical protection of the crop. 


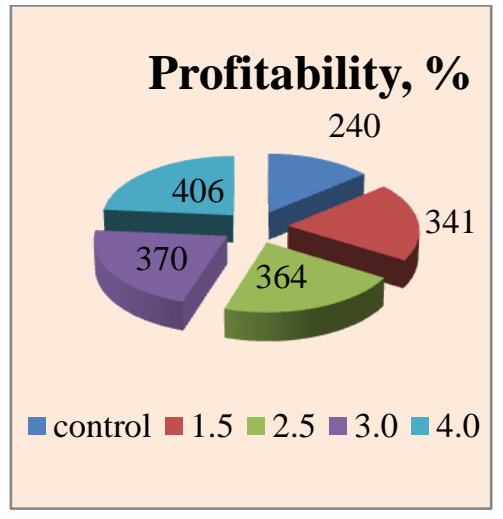

Fig. 2.6. Indexes of profitability in dependence on the application of Pulsar 40, L/ha, average for 2016-2018

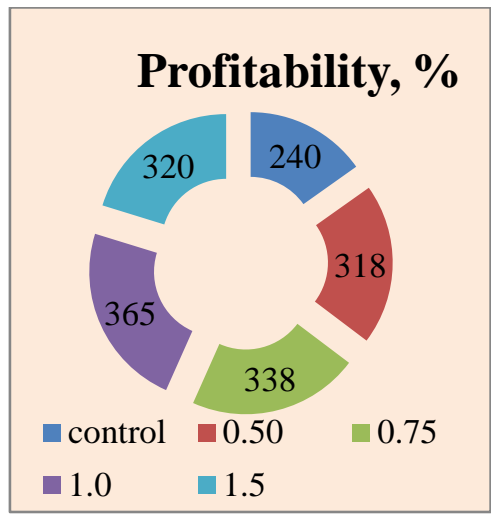

Fig. 2.7. Indexes of profitability in dependence on the application of Treflan 480 , L/ha, average for 2016-2018

Thus, the study conducted in 2016-2018 allow concluding that cultivation of annual white melilot variety Pivdennyi in combination with the improved elements of cultivation - application of the herbicides Treflan 480 and Pulsar 40 in the seminal crop is one of the major factors of the crop productivity formation and is closely dependent on the soil and weather conditions of the zone, agrotechnics and morpho-biological features of the plants. By the results of the analysis of three years of the study, the highest gross product value per 1 ha - 55,200 UAH was obtained at the crop of annual white melilot variwty Pivdennyi at the application of herbicide Pulsar 40 in the rate of $1.0 \mathrm{~L} / \mathrm{ha}$. The lowest production cost of $1 \mathrm{t}$ of seed material was also established on this variant - 13,800 UAH, the summarizing index of economic efficiency - profitability - was the highest and reached the value of $415 \%$.

\section{CONCLUSIONS}

1. The analysis of the conducted during 2016-2018 experimental investigations allowed concluding that application of different time of sowing and sowing rate in the agrotechnology is one of the major factors of the formation of the crop productivity and are dependent on 
soil and climatic conditions of the zone, cultivation technology and morpho-biological features of the plants of annual white melilot variety Pivdennyi.

2. The optimal conditions for growth and development of the annual white melilot plants formed at sowing in the I decade of April, when average seed yield was $0.86 \mathrm{t} / \mathrm{ha}$, at the same time, at sowing in the III decade of March it was $0.73 \mathrm{t} / \mathrm{ha}$, in the II decade of April $0.68 \mathrm{t} / \mathrm{ha}\left(\mathrm{LSD}_{05}=0.025 \mathrm{t} / \mathrm{ha}\right)$.

3 . The level of yield in the crop at the first sowing time was $0.58-0.83 \mathrm{t} / \mathrm{ha}$, at the second $-0.72-1.01$, at the third $-0.57-0.81 \mathrm{t} / \mathrm{ha}$, that allows recommending these elements for the improvement of seed production technology of melilot in the conditions of Southern Steppe of Ukraine.

4. The highest average seed yield of the crop - 1.01 t/ha in 2016-2018 was obtained at sowing in the I decade of April at the rate of 2.5 million pc./ha.

5. The maximum index of profitability $-355 \%$ - was obtained at sowing in the I decade of April; the minimum index - 256\% - was at sowing in the II decade of April. Among the studied sowing rates the maximum profitability of $342 \%$ was at the sowing rate of 2.5 million $\mathrm{pc} . / \mathrm{ha}$, the minimum one $-238 \%$ - at the sowing rate of 3.5 million pc./ha.

6. At the application of the herbicides, the maximum seed yield of annual white melilot was $0.92 \mathrm{t} / \mathrm{ha}$ at the application of Pulsar 40 herbicide with the rate of $1.0 \mathrm{~L} / \mathrm{ha}\left(\mathrm{LSD}_{05} \mathrm{~A}-0.042 \mathrm{t} / \mathrm{ha}\right.$, $\mathrm{B}-0.034 \mathrm{t} / \mathrm{ha})$.

7. The maximum gross product value per 1 ha of $55,200 \mathrm{UAH}$ at the lowest production cost of $1 \mathrm{t}$ of the seed material $(13,800 \mathrm{UAH})$ and the highest profitability of $415 \%$ was obtained in the crop of annual white melilot variety Pivdennyi at the application of Pulsar 40 herbicide with the rate of $1.0 \mathrm{~L} / \mathrm{ha}$.

\section{SUMMARY}

The article presents the results of three-year study dedicated to the investigation of the effect of sowing time, sowing rate and herbicides on the seed productivity of annual white melilot variety Pivdennyi in the conditions of Southern Steppe of Ukraine. The soil of the experimental field - dark-chestnut middle-loamy slightly saline, 
typical for Southern Steppe zone of Ukraine. The maximum average yield in 2016-2018 - 1.01 t/ha the crop formed at sowing in the I decade of April at sowing rate of 2.5 million pc./ha $\left(\mathrm{LSD}_{05} \mathrm{~A}-\right.$ $0.025 \mathrm{t} / \mathrm{ha}, \mathrm{B}-0.020 \mathrm{t} / \mathrm{ha})$. The maximum yield by the factor $\mathrm{A}$ (sowing time) $-0.86 \mathrm{t} / \mathrm{ha}$ - the plants of annual white melilot formed at sowing in the I decade of April $\left(\mathrm{LSD}_{05} \mathrm{~A}-0.43 \mathrm{t} / \mathrm{ha}\right)$. By the factor $\mathrm{B}$ (sowing rate) this index was the maximum at the rate of 25 million $\mathrm{pc} . / \mathrm{ha}-0.88 \mathrm{t} / \mathrm{ha}\left(\mathrm{LSD}_{05} \mathrm{~B}-0.35 \mathrm{t} / \mathrm{ha}\right)$. The maximum average yield in 2016-2018 at the application of the herbicides - $0.92 \mathrm{t} / \mathrm{ha}$ - the crop formed at the application of Pulsar 40 with the rate of $1.0 \mathrm{~L} / \mathrm{ha}\left(\mathrm{LSD}_{05}\right.$ $\mathrm{A}-0.042 \mathrm{t} / \mathrm{ha}, \mathrm{B}-0.034 \mathrm{t} / \mathrm{ha}$ ). The highest profitability $-415 \%$ - was obtained in the crop of annual white melilot variety Pivdennyi where Pulsar 40 herbicide was applied in the rate of $1.0 \mathrm{~L} / \mathrm{ha}$.

\section{REFERENCES}

1. Рудницький Б. О. Удосконалення елементів технології вирощування бобових трав на корм та насіння. Корми $i$ кормовиробництво. 2003. № 51. С. 43-51.

2. Коць С. Я. Фізіологічні основи підвищення насіннєвої продуктивності люцерни. Физиология и биохимия культурных растений. 2000. Т. 32, № 3. С. 163-170.

3. Петриченко В. Ф. Наукові основи інтенсифікації польового кормовиробництва в Україні. Вінниця: ФОП Данилюк В.Г., 2008. $246 \mathrm{c}$.

4. Шлапунов В. Н. Донник белый - конкурент люцерне и клеверу. Гомель: Белорусское сельское издательство, 2008. 446 с.

5. Кирпичев И. В., Наумов С. Ю. Однолетний и двулетний донник. Луганск: Укрроспроммаш, 2000. 356 с.

6. Влащук А. М., Прищепо М. М., Конащук О. П., Колпакова О. С. Буркун білий однорічний - перспективна кормова культура. Агроном. 2015. № 3(49). С. 216-218.

7. Сщенко В. О., Копитко П. Г., Опришко В. П., Костогриз П. В. Основи наукових досліджень в агрономії: монографія. Київ: Вид. Дія, 2005. С. 288 с.

8. Ушкаренко В. О., Вожегова Р. А., Голобородько С. П., Коковіхін С. В. Методика польового дослід. Херсон: Грінь Д. С., 2014. $286 \mathrm{c}$. 
9. Наумов С. Ю., Полищук С. П., Шелихов П. В. Местные популяции белого донника и их роль при селекции на продуктивность. Збірник наукових пращь Луганського державного аграрного університету. 2001. № 11(23). С. 71-74.

10. Архипенко Ф. М. Кормовиробнитво в умовах зростання посушливості клімату. Вісник аграрної науки. 1994. № 9. С. 36-40.

11. Бабич А. О. Методика проведення дослідів по кормовиробництву. Вінниця: Іскра, 1994. 87 с.

12. Макрушин М. М. Насіннєзнавство польових культур. Київ: Урожай, 1994. 208 с.

13. Голобородько С. П., Снеговой В. С., Сахно Г. В. Люцерна. Херсон: Айлант, 2007. 328 с.

14. Іващенко О. О. Бур'яни в агрофітоценозах: монографія. Київ: Світ, 2002. 236 с.

15. Швартау В. В. Гербіциди. Київ: Логос, 2009., Т. 2. 1046 с.

16. Мордерер Є. Ю., Мережинський Ю. Г. Гербіциди. Механізм дії та практика застосування. Київ: Логос, 2009, Т. 1. $380 \mathrm{c}$.

\section{Information about the author:} Vlashchuk A. M.,

Candidate (Ph.D.) of Agricultural Sciences, Senior Researcher, Head of the Department of Primary and Elite Seed Growing,

Institute of Irrigated Agriculture of the National Academy of Agrarian Sciences of Ukraine Kherson, Naddnipryanske, 73483, Ukraine 